\title{
Editor's Note to: Molecular taxonomic tools provide more accurate estimates of species richness at less cost than traditional morphology-based taxonomic practices in a vegetation survey
}

\section{David L. Hawksworth ${ }^{1}$}

(c) Springer Nature B.V. 2021

Readers are alerted that the reliability of data presented in this manuscript is currently in question. Appropriate editorial action will be taken once this matter is resolved.

Publisher's Note Springer Nature remains neutral with regard to jurisdictional claims in published maps and institutional affiliations.

The original article can be found online at https://doi.org/10.1007/s10531-014-0672-z.

David L. Hawksworth

d.hawksworth@nhm.ac.uk

1 Department of Life Sciences, Natural History Museum, Cromwell Road, London SW7 5BD, UK 